\title{
石清 水八幡宮本殿について
}

正会員土田充義*

\section{1. 序}

石清水八幡宮は守佐八幡宮から勧請されて, 貞観 2 年 (860) に本殿創建となる。現宇佐八幡宮は各棟別々の三 棟からなる本殿であるが, 現石清水八幡宮本殿は連棟で 西る。宇佐八幡宮から勧請されたことから一般には石清 水八幡宮は創建期に於て三棟からなる本殿と推定されて いるが，何時から連棟になったか恃重要なことであるに もかかわらず，資料不足もあって明確にはされていな い。本論文は石清水八幡宮本殿が連棟になった時期の推 定を試みたのである。推定する根拠は仮殿遷宮にあるの で，石清水八幡宮の仮殿遷宮についてまず述べ，次に連 棟となる時期の延久 3 年 (1071) の修理を詳述し, 最後 に宇佐八幡宮との比較加ら, 石清水八幡宮創建期本殿を 推察した。

\section{2. 仮 殿遷宮}

石清水八幡宮は貞観 2 年 (860) に本殿が完成し，御 肼の安置となった注 1$)$ 。貞観 7 年 (865) には大菩薩・大 帯命に御鞍を奉り，此羏大神には遅れて奉ることになっ た（日本三代実録 4 月 17 日）ことが書いてあるので大 菩薩・大帯命，比咩大神の安置であることが解る。

創建以来 103 年後の応和 3 年 (963) には本殿の修理 を必要としたが，陰陽寮御占の結果，大菩薩正座は移動 せず，3 月 27 日に工事着手し，4 月 13 日に完成した （石清水八幡宮御修理造営記，石清水文書之四）。応和 3 年以前の天德 4 年 (960) には損色を取っており, 康 保 3 年 (966) に修理が完了している（小右記, 長元元 年 10 月 19 日庚辰)。石清水八幡宮御修理造営記 と小右 記とでは修理をする期間が異なるが，天徳 4 年に損色を 取り, 応和 3 年に修理し, 康保 3 年に再び修理して完了 しているとすれば矛盾はない。しかし，明らかにする資 料はない。康保 3 年の修理にも「不動正御座」とあり, 御身注移動せずに貫の取替えと虹梁 4 本を取替えて新材 にしている。

小右記（長元元年 10 月 19 日）に

$\square$ 抑宇佐宮例, 奉移仮殿, 至礎改替者, 但一條

院御時, 被移仮殿修造, 以有國・唖使云々。(・印筆 者）とあり，一條天皇の時に仮殿遷宮が行われて，藤原 有国が勅使として石清水宮に行ったのである。しかし，

* 九州大学講師

（昭和 47 年 6 月 29 日本稿受理 -討論期限昭和 48 年 2 月末日）
一條天皇の時の仮殿遷宮の根拠は「先奉移仮殿修造御, 是宮寺司依舊記申也」(小右記長元元年 10 月 13 日) と あって旧記に基づいて述べているのであるし，一條天皇 の時期は本殿造替や修理の記録はないので仮殿遷宮が実 際に行われたかどうか疑問である。

長元元年 (1028) には御躰を移動せずに本殿の修理が 行われた（左経記 11 月 2 日)。翌年の長元 2 年には本 殿北高欄と前後犬防, 幣殿, 南楼階日隠等が始めて造ら れた注2)。

天喜 4 年 (1056) には宝前大迴筑が造られ，廻築の先 端には馬場殿と飯殿とが創建された（石清水入幡宮史第 一輯）。古絵図注3（図一1 参照）に示す迴廊外側の大迴 した築地塀が「宝前大迴築」であろう。楼門の前方にあ る二棟のうち右手（楼門を背にして）が飯殿，左手が馬 場殿と記入されている。古絵図に描かれている建築の様 子は鎌倉時代末期を降らぬもの（神社古図集，電通出版 部, 昭和 17 年) ではあるけれども，古絵図に描かれて いる如く天喜 4 年には迴廊を囲んだ築地塀が建てられ， 飯殿，馬場殿が創建された。

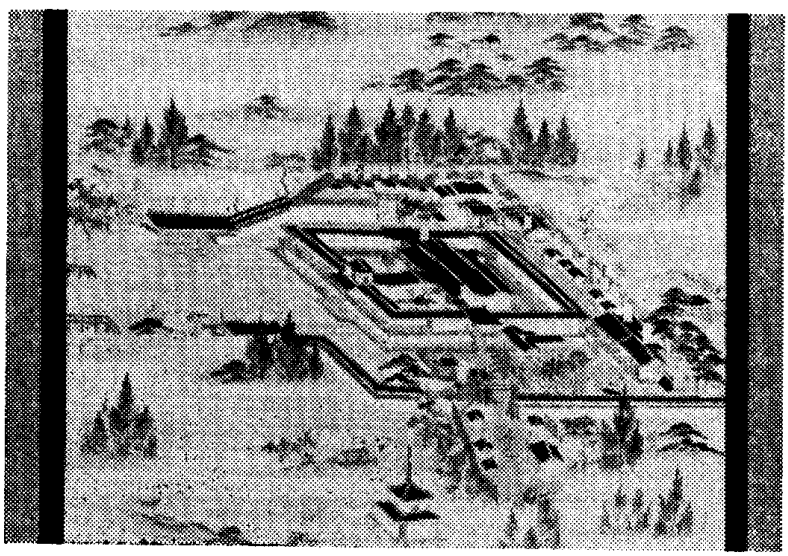

図-1 谷村家所蔵の古絵図

延久 2 年注4)（1070）と延久 3 年注5) とに本殿の修理が 行われたが，次項に譲り，省略する。

寛治 3 年 (1089) に本殿を修理する（陰陽寮日時勘文 石清水文書之一）が，工事内容及び遷宮に関しては別に 記入はない。

嘉承 2 年 (1107) 2 月 19 日には本殿修理が行われて いる（石清水文書之一）が，工事内容及び遷宮に関して は別に記入はない。

天仁 2 年 (1109) 7 月 9 日に本殿修理をしている（石 
清水文書之一）が，簡単な修理であったのか，工事内容 や遷宮に関しては書いていない。

大治 3 年（1128）に流茂家栄日時勘文（石清水文書 之一) に

擇申可被改替石清水宮, 御殿樋日時

$$
\begin{array}{rrr}
\text { 今月廿一日 } & \text { 甲戍 } \text { 時巳未 } \\
\text { 廿七日 } & \text { 庚辰 } \text { 時午申 }
\end{array}
$$

大治三年四月十一日陰陽頭賀茂朝臣家栄

とあり，内殿と外殿との間の樋と思われるが，改めて替 えられている。遷宮に関しては別に記入はない。

保延 6 年 (1140) には貞観 2 年の創建以来最初の火災 を受け，本殿，廻廊，宝蔵，若宮は焼失した（百錬抄， 十三代要略二)。火災の折，御躰は護国寺に遷座した。 焼失後まもない 2 月 29 日には立柱上棟が行われ，同年 4 月 2 日には再建した本殿に護国寺より正遷宮となる (石清水文書之一，十三代要略二)。

長寛元年 (1163) 御躰を外殿に移した後に内殿を修理 するのを望むが，仮殿遷宮の例がいままでないというこ とで許可されず（石清水文書之一），中御殿と四面廊を 修理した。又この時西門脇に鉝御座が創建された注6)。

承安 4 年 (1174) には内殿妻戸，登橋等と西御前の北 西の土居，北と西 1 間ずつの柱下長押が修理された（石 清水八幡宮造営遷宮等舊記抄出)。仮殿遷宮に関しては 書いていない。

寿永 2 年 (1183) の修理で外殿に御躰を移してから内 殿の修理を望むのであるが，前例がないといらことで遷 宮されずに 6 月 22 日に修理する（石清水八幡宮御修理 造営之記）。陰陽寮日時勘文（石清水文書之一）には修 理する日時のみ記入で, 遷宮の日時が書いていないこと も外殿には移されなかったことを示している。

建久元年 (1191) には検校成清が非常に破損した内殿 を修理するために，仮殿遷宮を願らが，先例のないこと で実現出来ない（玉葉，建久元年 7 月 1 日）。内殿は破 損しているし，仮殿遷宮は許されない結果放生会の「一 日御修理」が建久 4 年 8 月 15 日から始まる。 8 月 15 日の放生会で御躰は御興に乗って極楽寺へ移った 1 日間 に修理する企てである(百錬抄)。1 日の修理で終るに はなかなか大変で, 219 人（大工 83 人，檜皮工 100 人， 壁工 6 人，金物細工 19 人，朱砂塗 5 人，鐉治 6 人)注 7 ) の動員で成し遂げ得ることが出来た。その結果賞として 検校成清は筑前国香椎領 36 ケ所を受け，正治元年 (11 99）には成清の弟子竹清が香椎宮検校に補任された（石 清水八幡宮御修理造営之記)。

建久 6 年 (1196) 7 月 19 日には内外殿間に板敷が始 めて敷かれた（八幡宮寺縁事抄）。

承久元年 (1219) の放生会の「一日御修理」では内殿 を修理するが注8），建久 4 年の修理から僅か 25 年しか経 過していないせいか，建久 4 年の「一日御修理」の半分
の「諸庄召物」で足りた。言葉通り極楽寺へ遷宮した I 日間の修理である。

文永 8 年 (1271) 8 月 15 日の「一日御修理」に内殿 三ケ所, 外殿, 武内社の修理が行われ, 承久度修理より 53 年経過して大分破損していた（石清水八幡宮御修理 造営之記）。石清水八幡宮記録（石清水八幡宮史所収） には修理に使用した材木が詳しく書いてある。1 日修理 では大変な量であるが，未刻には終っている。

検校善法寺宮清の院宣に対する請文に

内殿御修理事, 代々雖有沙汰, 依難儀不終其功, 曾 祖父成清之時, 第三方之沙汰放生會之間, 一日中奉 修理事, 始佳例候, 其時入夜奉終功候钦, 今度一向 爲社家沙汰致沙汰候, 未克奉終功候畢, 言社家一方 言率爾之功, 超過先々, 隨分忠之由相存候之處, 如 此如被仰下候之條，殊畏入候之由，加御詞可有御披 露候, 宮清恐惶謹言，

\section{（文永八年）八月十九日 法印宮清請文}

追啓

建久承久兩度雨降候骬, 今度天晴候, 工等之中一人 モ無其煩候，神慮令然候职，外殿并武内御修理此間 致沙汰候, 既可終功日, 此沙汰之間, 可令候宇社頭

候，重謹言，(・印筆者）（石清水八幡宮記録）とあ る。この文章から「一日御修理」の沙汰について詳しく 解る。建久承久両度の修理には朝廷からの沙汰のもとに 行ったが，今度の文永 8 年の「一日御修理」は社家の沙 汰で修理を行ったのである。更に宮清は修理の沙汰は社 家で行えるようにと願っている。建久 4 年の検校成清の 始めて行った放生会の「一日御修理」は良い先例である といっており，建久度に於ける修理は朝廷の沙汰のもと に，雨の中で行ったのである。文永 8 年の検校宮清によ る修理は社家のみによる沙汰で，晴天に行った。本殿修 理に当っては実に重要な変化である。

元享 4 年 (1323) には宝前楼門前の階段は始めて石造 にした（八幡宮寺縁事抄）。

建武 5 年 (1338) 7 月 5 日丑刻に馬場殿より火が出て， 本殿, 武内社, 若宮, 若宮殿, 経蔵, 鐘楼, 小社等が焼 失した（石清水八幡宮記録）。

8 月 1 日には杣に入り，材木を採り，8月 11 日に木 作を始め，10月 13 日立柱上棟を行う計画であった（石 清水八幡宮御修理造営之記）が，実際は後れて 11 月 25 . 日立柱上棟になり，12月 14 日遷宮が行われ，12月 15 . 日には 8 月 15 日の放生会が後れて行われた（石清水入 幡宮末社記)。建武 5 年の第二回目の火災では内殿三所 の御躰と外殿の御躰とは第一回目の保延 6 年 (1140) の 火災の時と同様護国寺に移された（中院一品記）。

応安 4 年 (1371) 4 月 5 日には中村の住人 7 人が内殿 中御前で自害をし，神宝等が血に染って神にとっては秒 
事となり，造替をするにいたった（石清水八幡宮御修理 造営之記)。 5 月 19 日の宣旨により, 造営の日程が決 められ，5 月 26 日入杣採材， 7 月 9 日木作始为， 8 月 10 日立柱上棟になった。実際には 10 月 25 日立柱上 棟，12月 11 日正遷宮となった。これより先御躰を護国 寺か若宮のいずれに遷宮すべきか, 又中御前のみの造替 か, 内殿全部の造替かの詮議があったが, 神祇管占文よ り, 若宮への遷宮, 内殿全体の造替となる。内殿三所御 躱を若宮へ遷宮する栜裁が出され，5月 8 日遷宮した (大外記師茂記，石清水八幡宮御修理造営之記）。

創建以来仮殿遷宮はなく，ただ延久 3 年 (1071) の馬 道への遷座を除いては各修理の一度たりとも外殿へも仮 殿へも遷宮は認められなかった。社家にとってはたえず 遷宮してから後の修理を願っていたのであるが，許され ることはなかった。修理する側にとっては仮殿遷宮なし の修理は非常に困難なことである。応安 4 年は創建以来 始めての内殿取り毁しての造替であるから，遷宮せざる を得ない理由もあるが，文永 8 年 (1271) の宮清請文に 表現される如く, 社家の沙汰に基づいて修理が出来る動 きからも仮殿遷宮へ向いつつあるのが推察出来る。仮殿 遷宮して後に造替・修理する最初が応安 4 年である。

嘉慶 2 年 (1388) 2 月には流血の騒ぎがあったため, 御射を若宮へ遷宮して修理が行われた（石清水八幡宮御 修理造営之記)。

応永 6 年 (1399) 8 月 15 日には「一日御修理」で, 内外殿の莫替が行われ，応永 11 年（1404）には諸末社 が遷宮されて, 造替が行われた（石清水八幡宮御修理造 営之記)。

正長 2 年 (1429) 3 月 15 日に仕丁 2 人が外殿の大床 で腹を切って死亡したため, 3 月 24 日には釿始めがあ り，29 日 1 日間修理が行われた（石清水八幡宮御修理 造営之記)。遷宮のことは書いてない。

永享 6 年 (1434) には社頭并山上山下が造営されてい る(石清水八幡宮御修理造営記) が, 本殿のどの部分が 修理されているのか不明で, 遷宮に関しては書いてな w。

永享 13 年 (1441) には若宮の棟瓦莫替に御射を外殿 の中御前に遷宮している（石清水八幡宮御修理造営之 記)。

長禄 2 年 (1458) 2 月 11 日には当宮所々并護国寺御 修理とある（石清水八幡宮御修理造営之記）が, 本殿の 何処を修理したのか不明。仮殿遷宮も不明。

文明 18 年 (1486) 9 月 2 日に狼藉により, 内外殿に 流血の騒ぎがあって造替をするために 9 月 15 日夜に若 宮への遷宮が行われた。遷宮して 3 年後の長享 3 年 (14 89）８月にまだ造替が完成しないので御帚座の遅延を検 校法印奏清は願い出ている（石清水八幡宮御修理造営之 記)。
建久 4 年 (1194) の「一日御修理」からすると 3 年間 の仮殿遷宮とは大きな変化である。何時御帰座したのか 資料はない。

永正 5 年 (1508) 2 月 23 日には第三回目の焼失に会 って, 御身は大塔に移され，2 月 27 日は仮殿建立を善 法寺雑掌に命じている（石清水八幡宮文書, 石清水八幡 宮史所収）ので正遷宮の行われる大永 6 年 (1526) 2 月 16 日までの 20 年近い間仮殿に安置されたのであろう。 仮殿は若宮かどうか不明。若宮も焼失しているので他に 仮殿を建立したのかもしれない。

天正 8 年 (1580) 2 月 18 日には三所御身を若宮御殿 に遷宮して 屋根の莫替と樋を銅に造り替えた工事を行 い，6 月 27 日正遷宮を行った。天正 17 年 (1589) に は豊臣秀吉の母の病気回復を祈って廻廊を再建した（石 清水八幡宮御修理造営之記)。

慶長 5 年 (1600) より慶長 13 年 (1608) の間豊臣秀 頼によって内・外殿に始まり, 未社堂塔の造替及び修理 の工事が行われた。慶長 11 年 3 月 23 日には仮殿遷宮 の日時が決められ, 同年 3 月 25 日仮殿遷宮になる（石 清水八幡宮御修理造営之記)。この仮殿遷宮はどこに遷 宮するのかといえば，「假殿若宮御殿云々」（壬生家四巻 之日記四）とあるし，石清水八幡宮御修理造営之記に慶 長 11 年 3 月 25 日三所御躰を若宮に遷宮したとあるの で, 仮殿遷宮は若宮へ遷宮したのが解る。仮殿遷宮後造 替られ，同年 12 月 11 日に正遷宮が行われた。

寛永 8 年 (1631) には「石清水八幡宮神社佛閣破損目 録」に造替を必要とするのに本社内外殿付武内社, 楼 門, 廻廊が書いてあり，同年 12 月 21 日仮殿遷宮が行 われた（石清水文書之二)。破損目録に若宮の名はない し, 前の慶長 11 年の仮殿遷宮は若宮へ遷宮しているこ とから, 寞永 8 年の仮殿遷宮は若宮遷宮のことであろ 5 。寬永 9 年 11 月 4 日立柱上棟で, 仮殿遷宮から 2 年 8 ケ月後の寛永 11 年 8 月 22 日に正遷宮が行われ, 現 本殿の建築が完成した（石清水文書之二）。

寬文 5 年 (1665) 6 月には仮殿遷宮を行い, 修理後翌 年 12 月 14 日には正遷宮が行われた（石清水文書之六)。

元禄 4 年 (1691) 11 月 21 日には仮殿遷宮を行い, 元 禄 6 年 9 月 2 日に正遷宮が行われた (公卿補任)。元禄 度八幡宮正遷宮図（石清水八幡宮史第一輯）には若宮仮 殿と書いてありそそこから本殿への正遷宮が示されてい る。

延享元年 (1744) 9 月 18 日仮殿遷宮を行い, 修理後 延享 2 年 11 月 14 日に正遷営を行った (公卿補任)。

安永 7 年 (1778) 3 月 27 日に仮殿遷宮を行い，修理 後同年 8 月 1 日に正遷宮を行った (公卿補任)。

文化元年 (1804) 11 月 7 日に仮殿遷宫を行い（公卿 補任)，簡単な修理だけと見えて同年 12 月 17 日に正 遷宮を行った (定業卿記)。 


\begin{tabular}{|c|c|c|c|c|}
\hline 年 & $\leftarrow$ & 仮殿逗宣 & I 事 容 & 典 㧋 \\
\hline 真䚁2年 & 860 & 御射安是 (三座) & 本殷創电 & 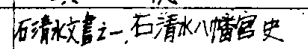 \\
\hline 真観 7 年 $4 A / 78$ & 865 & 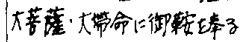 & & 三大实銭 \\
\hline 応和3年 & 963 & 御射動から声”。 & 修理 & 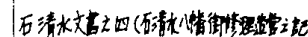 \\
\hline 康保3年 & $\begin{array}{l}966 \\
986 \\
10^{3} 11\end{array}$ & 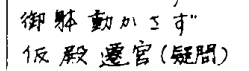 & 䔁七虹深4广取替 & $\begin{array}{l}\text { 小右記 } \\
\text { 小右敦(是元元年10月13日) }\end{array}$ \\
\hline 長元元年 & 1028 & 御射動かさず & 修 理 & 左絰就 \\
\hline 長元2年 & 1029 & & 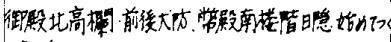 & 必，石清水文草之四 \\
\hline 天童4年 & 1056 & & 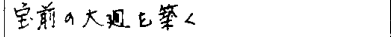 & 石啨水八愔官文 \\
\hline 延久2年 4月29日， & 91070 & 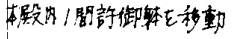 & 氟一御殿风修理 & 泀清水文草之四 \\
\hline 延及3年 & 1071 & & 乖二御殿、 梁取智 & 西清水文宣之四 \\
\hline 征入3年4月9日 & 91071 & 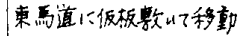 & 忒三御殿の修理 & 百钴抄 \\
\hline 宽治3年 & 1089 & & 修理 & 石清水文昔之一 \\
\hline 㚌承哖 & 1107 & & 修理 & 石清水文要之一 \\
\hline 天仁 $Z$ 年 & 1109 & & 修理 & 石清比八憣宫史 \\
\hline 太治3年 & $1 / 28$ & & 御殿の䖽巨改め替える & 石清水文著之一 \\
\hline 保延上年1月23日 & $8 / 140$ & 檴国寺へ移方 & 烧失 $($ 为一国) & 后清水文草之一 \\
\hline 保延b年 4月2B & $8 / 140$ & 薯国寺より正要宫 & 再建 & 死清炆划士一十三代要胳二 \\
\hline 長䆜元年 & 1163 & 外殿への遭座許っはず & 中御殿と西面、廊修理 & 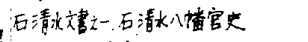 \\
\hline 殎安4年 & 1174 & & 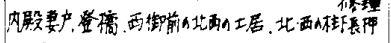 & 石清水八嘌宫史 \\
\hline 寿永 z年 & 1183 & 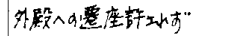 & 修理 & 石清水文地四 \\
\hline 建入4年8月15日 & 1194 & 1日程楽寺へ整來 & 屋根小䒴替 & 百锢抽 \\
\hline 延入6年7月19日 & 1196 & & 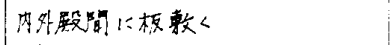 & 石清水八幡宫史 \\
\hline 聎及元年8月15日 & 1219 & 1日極䅛寺人逶座 & 修理 & 石清水交急之四 \\
\hline 文永8年8月15日 & $127 !$ & & 修理 & 石湷水文書之四 \\
\hline 建武5年7月5日 & 1338 & 境国寺へ移す & (戒=回) & 碃水八橎宫史 \\
\hline 建武5年/2月14日 & $9 / 338$ & 愎国寺より正要宫 & 再建 & 石消水文费之四 \\
\hline 応安4年5月8日 & 1371 & 仮殿整富(若宫) & 峼替 & 泀清水文昔之四 \\
\hline 父安4年/2月11日 & 1371 & 正整宫 & & 石清水文茟之四 \\
\hline 䁏秦2年 & 1388 & 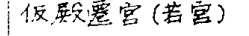 & 修理 & 石清水文管之四 \\
\hline 応永6年8月15日 & 1399 & & 内外殿、喜替 & 若清水文童之四 \\
\hline 正長2年 & 1429 & & 修理 & 若清水文著之四 \\
\hline 永享年 & 1434 & & 社頭手山上下所戊造赏 & 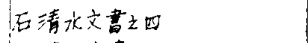 \\
\hline 永享!3年 & 1441 & 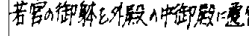 & 官若宫a楝瓦修理 & 互清水文疌云四 \\
\hline 長沝2年2月11日 & 81458 & & 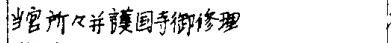 & 西清水文書地 \\
\hline 文明18年9月15日 & $8 / 486$ & 仮殿要葟(若宫) & 造替 & 石清水文费之四 \\
\hline 長亨3年 8月 & 1489 & 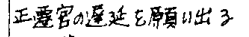 & & 石清北文書之四 \\
\hline 永正5年2月23日 & $8 / 508$ & 大塂八移す & (忒三国) & 石清胁八煌官史 \\
\hline 大补年 2 月16日 & 8,526 & 仮殿より正要富 & 拜建 & 在清水文書え四 \\
\hline 天正8年2月18日 & $8 / 580$ & 仮殿透宫(若宫) & 青替と桶七銅にする。 & 石清水文昔之四 \\
\hline 天正8年6月27日 & A, 1580 & 正逥宫 & & 石清水文書之四 \\
\hline 鹿長11年3月25日 & $8 / 606$ & 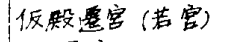 & 造替 & 石清水文亶之四 \\
\hline 旁長11年/2月11日 & 81606 & 正遭宫。 & & 石清水文書之四 \\
\hline 宽永8年/2月2/日 & $8 / 63 \mid$ & 仮殿垔宫 & 造替 & 石清水文書之二 \\
\hline 寛永:1年 8月2Z日 & 161634 & 正蹗宫 & & 石清水文書之二 \\
\hline 宦文5年6月 & 1665 & 仮殿雾宫 & 修理 & 西清水文書之六 \\
\hline 宽文6年12月14 & $18 / 666$ & 正遷富 & & 石潘水文書文六 \\
\hline 元禄4年11月21. & $\begin{array}{l}18 \\
30691\end{array}$ & 仮层䇾宫 (若官) & 修理 & 公榔補任 \\
\hline 延辛元年9月188 & $\begin{array}{l}8.643 \\
88,1744\end{array}$ & 仮殿篦密 & 修理 & $\begin{array}{l}\text { 公卿補任 } \\
\text { 公卿神通任 }\end{array}$ \\
\hline 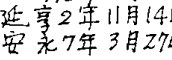 & $\begin{array}{l}48,745 \\
78,778\end{array}$ & 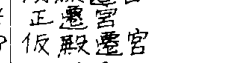 & 修理 & 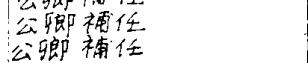 \\
\hline 安永7年8月1日 & 日/778 & 正䠛官 & & 公卿補任 \\
\hline 文化元年 11 月 $7^{8}$ & 1804 & 仮殿曾宫 & 修理 & 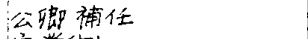 \\
\hline 文化元年 12 月! 7 E & 1804 & 正䞹宫 & & 定業卿梓 \\
\hline 文化9年9月3日 & B 1812 & 仮殿鍟富 & 修理 & 公剆補任 \\
\hline 文化9年12月21 & $18 / 812$ & 正遥宫。 & & 伊光 瑯耙 \\
\hline 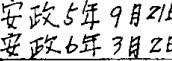 & $\begin{array}{l}18 / 858 \\
2 / 859\end{array}$ & 仮殿要官 & 修理 & $\begin{array}{l}\text { 公啷㭪任 } \\
\text { 公啷補任 }\end{array}$ \\
\hline
\end{tabular}

\section{図-2}

続いて文化 9 年 (1812) 9 月 3 日に仮殿遷宮を行い (公卿補任), 修理後同年 12 月 21 日に正遷宮を行。 た (伊光卿記)。

安政 5 年 (1858) 9 月 21 日には仮殿遷宮を行い，修 理後安政 6 年 3 月 2 日に正遷宮を行っている（公卿補 任)。

以上の仮殿遷宮の 歴史をまとめて 表にしたのが図一2 である。この表から解るように遷宮が行われるようにな ったのは応安 4 年 (1371) の造替以来の事である。石清
水八幡宮は創建以来応安 4 年まで 仮殿遷宮による修理がいかに困難 であるか理解出来るし, 谷重雄博 士が指摘されるように「一日御修 理」（建築史 1 の 2 ）が生まれる 理由も理解出来る。本殿焼失に際 しては護国寺に遷宮し，放生会の 1 日間は極楽寺に遷座している。 仮殿遷宮は若宮への遷宮である。

\section{3. 延久 3 年 (1071) の修理}

延久 2 年には第一御殿を修理す るのに仮殿を設けて遷宮するかど うかの議論が陰暦権助安倍有行と 陰暦博士賀茂道平との間に戦わさ れ，仮殿遷宮の是否が論ぜられた が，結局賀茂道平の主張する「问 有其崇欺」が受け入れられて仮殿 遷宮は許されず，建立した仮殿は 取毁しとなった（石清水御修理御 占勘文延久二年, 石清水八幡宮史 所収の石清水八幡宮文書)。その 結果同年 4 月 29 日に本殿内 1 䦓 程御躰を移動して修理することに なった注9)。

延久 3 年 3 月に注第二殿の木作 が始められ，破損した梁を造替え る工事である。翌月の 4 月には第 三御殿の御射を東馬道へ遷座して 修理する。

延久三年四月九日寅刻, 奉上遷二 石清水宮西第卞御射。作レ帳奉 レ移二東馬道一其後始二造作-。未 時奉レ渡二本所一动々。（百錬抄 第五・印筆者）に示す如く，帳の まま東馬道に移し, その日の未時 (午后 2 時) に本所に帰っている。 石清水八幡宮御修理造営之記。

（石清水文書之四）に

擇申可被修造 御殿雜事日時 四月五日庚申時巳午 奉渡御躰於假板敷日時

$$
\text { 九日甲子 時寅記一巻有 }
$$

奉還御躰日時

$$
\begin{array}{ll}
\text { 十五日庚午 } & \text { 時亥 } \\
\text { 甘二日丁丑 } & \text { 時成 }
\end{array}
$$

\section{奉渡御軼於假板敷事} 以件日時被奉渡熼

弁史等参任也, 但白内奉道御也

延久三年三月廿日主税頭賀茂朝臣道平（・印筆 
者)とあり，4月9日寅刻に仮板敷に御躰を移し，その 日のらちに本所帰座している。仮板敷に御泍が安置され ている間弁史等仕えている。更化石清水八幡宮記録（延 久 3 年 3 月 1 日) に「㗹馬道間敷假板敷奉遷御殿御帳事」 とあり，馬道に仮板を敷いて帳のまま御躰を移したこと が明確になる。

次に馬道の位置は保延 6 年 (1140) 以後の建久 3 年 (1193) 10 月 11 日の石清水八幡宮記録に

䓨宮内殿馬道間子細事

右，件馬道間所司等申云，令修造西御前破損物，仍 奉渡中御前與東御前馬道間，令致沙汰云々，此申狀 無其謂欺, 延久宣命云, 元乃御殿乃内莨加, 當御在所 天朽損莨车物乎修造世程波, 傍間雨奉遷天, 令致其勤 云々, 就之案之, 中御前與西御前造合間欺, 奉移件 間, 被加修補之條, 又旁有不審, 其故者, 宣旨云, 馬道間敷假板敷, 奉遷御殿御帳云々。如宣旨狀者,

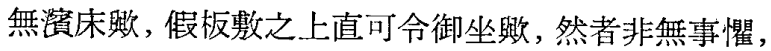
被用濱床者, 傍間之條非無不審, 件造合䦓五尺五寸 間一間也，濱床者六尺七寸之故也，以下略，(・印 筆者）とある如く中御前と東御前との間を馬道間といっ ている。法眼道清は馬道の間に仮板を敷いて御本を移し たことに疑問をもっている。この疑問は延久 3 年の馬道 間を解く鍵ともなるので後から馬道の柱間について述べ る所に譲るとして，馬道の位置を先に明確にしておきた い。石清水八幡宮記録（建久 3 年 10 月 11 日）の造合 間が馬道であるといえる。石清水八幡宮所蔵の平面図 (図一-3 参照) に見える「西御前御座」が第三御殿であ り,「東御前御座」と「中御前御座」との間の「造蓬」 が東馬道である。

内殿と外殿との間についてみてみる。小右記に

長元元年十月十九日庚辰 (中略) 猶可奉造改者, 先奉 移外殿, 造内殿了, 如元奉移内殿, 又奉造外殿可宜貼

(以下略) とあり，まず御射を外殿に移してから内殿 を修理し, 次に内殿に帰座して外殿を修理することを述 べている。第一回焼失前の大治 3 年 (1128) には樋が改 め替られている（石清水文書之一）。石清水八幡宮記録

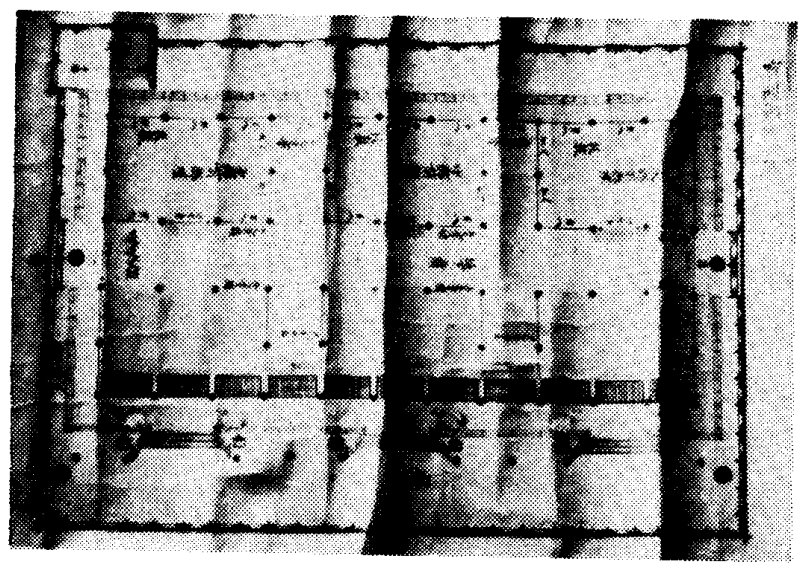

图-3 建久 6 年 (1196) 以前の平面図
（建久 3 年 10 月 11 日）に「内殿與外殿樋下」とあり， 内殿と外殿との間を建久 3 年には「樋下」といい，延久 3 年には内・外殿間には樋が懸けてあって八幡造になっ ていた。

馬道間について更に詳しく調べてみると，石清水八幡 宮記録（延久 3 年 3 月 1 日）に

口辨官下石清水八幡宫護國寺

憵馬道間敷假板敷奉遷御殿御帳事

(有)

被今月十九日宣旨狀

侮，右 $\square \square \square \square \square \square$ 板頽落之由，彼宮所司并工等，先 日所注進也, 宜仰彼宮寺, 御殿御帳暫奉遷近邊, 令造 替件梁者, 所請如件者, 又御殿司等解狀侮, 今案 $\square \square$

$\square \square \square \square \square \square \square$ 間三間也，弘一丈一尺，長一丈六尺口

$\square \square \square \square$ (演) 火桶等，奉行寄遷御裝束，已及二間，就中 $\square \square \square \square$ 西 間壁邊武内御射所御坐也者，上梁之間， $\square \square$ 下 $\square \square \square$ $\square \square \square$ 并三御殿可奉移貼，然者兩所御射 $\square \square \square \square$ 令移 動隨悎御定可申行之狀, 所請如件者, $\square \square \square$ 宣奉, 栜, 宜仰被宮寺，馬道間敷假板敷早令奉遷，兼又所注進假 殿御裝束等, 任色目令候, 若有 $\square \square$ 用事, 其時用之者 宮寺宜承知，依宣行之，

$$
\begin{aligned}
& \text { 延久三年三月一日 右大史小野 } \\
& \square \square \square \text { 藤原朝臣 （・印筆者） }
\end{aligned}
$$

とあり，浜床（幅 6 尺 7 寸） と御帳（図一 4 参照, 上記 の次に揭載されている絵図) のまま馬道䦓に仮板を敷い て移したのである。少くとも馬道の柱間は 6 尺 7 寸以上 はあったであ万う。先に述べた石清水八幡宮御修理造営 之記（注 5 の後半）では仮板を敷き始めるのが 4 月 5 日 であり，仮板敷に御射を移すのが 4 月 9 日である。 4 日 間のうちに本殿と同じ床の高さ程に仮板が敷かれ，北側 も板で遮断し，破風板間は覆われて，仮りに数時間の間 といえども御觔の安置する所であるからには仮殿の如く 周囲は覆い囲をれていたとするのは自然であるう。

保延 6 年 (1140) の第一回燒失後再建した本殿の馬道 間を子細に述べた石清水八幡宮記録（建久 3 年 10 月 11 日）で，馬道間に仮板を敷いて御躰を移したことへの検 校道清の疑問は馬道間（造合間） 5 尺 5 寸に 6 尺 7 寸の 浜床を敷くことはできないことに基ついている。更に同

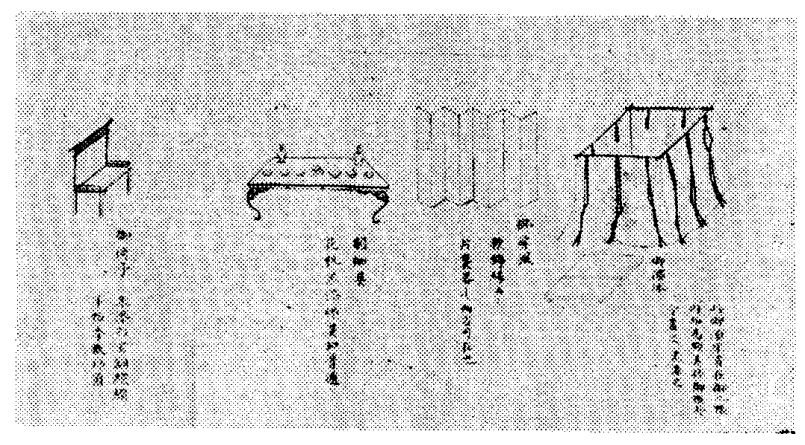

図一4 御帳・御浜床 
文書に内殿與外殿樋下尤得其理舆, 就中以往反路號馬道 之條,

貴賤諸家之習也, 口内殿造合間, 稱馬道之由, 彼奉行 弁正家朝至令申之旨所記置也者, 被尋件後胤, 何 $\square \square$ 隠哉, 内殿造合間重往反之路, 北者郎御殿後壁也, 難 謂馬道壆，以下略，(・印筆者）と述べて，内殿と外 殿との間の樋下が最も遷座する理に叶っているといって いる。遷座する理に叶っているとは樋下が 6 尺 7 寸以上 の柱間寸法であるからなのだろう。造合間は北壁があっ て往復の路ではなく馬道とはいえないと述べている。検 校道清が馬道間を子細に述べているのは保延 6 年(1140) 火㷋以後の馬道間を説明している。火災以前の延久 3 年 (1071) の馬道間は 6 尺 7 寸以上の柱間で北側には壁が なかったが，火災以後の建久 3 年 (1193) の馬道間は 5 尺5寸の柱間に狹められ，北壁を設けて「造合間」と呼 ばれれいた。延久 3 年に馬道間に仮板を敷いて遷座した ことは三所御殿が連続する要因になり得たのである。

\section{4. 結 語}

石清水八幡宮は宇佐八幡宮（図一5 参照, 現本殿) か ら勧請されて，貞観 2 年 (860) に内殿外殿からなる本 殿が創建した。勧請されるが故に同じ御躰が安置され祭 られるのである。同じ御射が安置されるからといって本 殿建築の形態をで同じであるかどうかは一概に云えない けれども，宇佐八幡宮から石清水八幡宮が成立する事情 を述べた文書の中から見てみると，

類聚國史巻五（神祇五，八幡大神）

貞観十八年八月十三日丁巳。石清水八幡護國寺申牌 侮。故傅燈大法師位行教。「法師」去貞観二年。奉二-

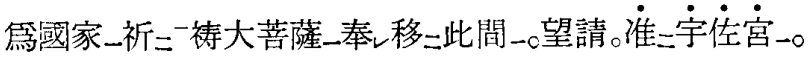
永置二神主-。剆以二從八位上紀朝臣御豊-爲一之。轩從 之。(・印筆者)

石清水八幡宮護國寺（石清水文書之五, 宮寺縁事抄第 十三)

略記, 三所大菩薩移坐男山岑, 郎奉安置御射焉後代縁 起事

（前略）今奉此奏狀也, 仍警貴所令奉造御殿也云々,

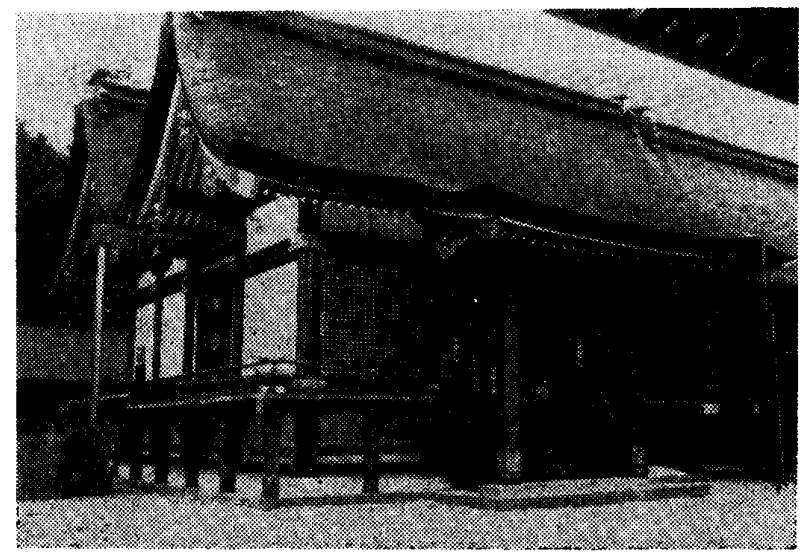

図一5 宇佐八幡宮本殿
剆緘應無極, 上上啓上件事由，還参石清水御山，奉頂 礼，准本宮例，勤仕祭祠祈裙之勤，(以下略）

貞観五年正月十一日

建立座主大安寺傅登大法師位行教 (・印筆者) と述べる如く，類聚国史では「准二宇佐宮一」とあり，石 清水文書には「准本宮例」とある。ここで述べている宇 佐宮に准ずるとは祭祀に関することであり，建築の形態 ではない。しかし，祭祀に関する類似性だけではなく， 本殿建築に関しても類似性はあり得るであろら。

宇佐八幡宮は天平 9 年 (739) に

夏四月乙巳㡿|。遣二使於伊勢神宮。大神社。筑紫住吉。

分幡三社及香椎宮_。奉_幣以告=新羅无禮之狀-。（・印 筆者)（続日本紀）とあり，八幡二社が存在している。

石清水八幡宮護國寺略記（石清水文書之五）に「去貞 観元年, 参拜筑紫豊前國宇佐宮, 四月十五日参着彼宮,

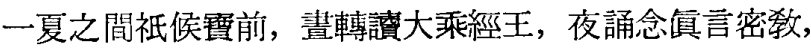
六時不断, 奉廻向立所犬菩薩也，(・印筆者)」とあり, 勧請される時には三社が存在している。二社から三社一 の増加は三社別棟の本殿と考えられる。まだ石清水八幡 宮本殿の創建期建築が明確にされていない時に宇佐八幡 宮本殿との類似性である三社別棟の本殿は 無視出来な い。

先学の谷重雄博士が連棟本殿の原因について「本殿が 横に三宇連棟の形式を採った事の原因は恐らく地形上の 関係加らと思わ礼，南北に長い峯の上に東西に相当の拡 がりを持つ社殿を建てる爲には己むを得なかった事であ ろらし，当時四面廻廊の計畫があったものとすれば，尚 更横幅を圧縮する必要を生じた事であ万う。」（建築史 1 の3「石清水八幡宮社殿下」）といわれるように敷地の 狹さは柱間寸法を 5 尺 5 寸と狹く寸ることと同様, 御殿 と御殿との間も狹くすることは行われたことであろう。 宇佳八幡宮の創建期の柱間寸法を明確にせずに比較する ことは出来ないのであるけれども，現宇佐八幡宮本殿の 柱間は $2.42 \mathrm{~m}$ ( 8 尺弱)，内殿と内殿との間（図一 6 参 照）は $4.13 \mathrm{~m}$ (13.6 尺強) で石清水八幡宮の柱間の方 が咴くなっている。

延久 3 年 (1071) の修理を基礎にして, 石清水八幡宮 本殿の創建期の建築を考えてみるに，内殿と外殿との間 は樋を賏け，本殿三所の破風板を接近させつつも（図一 6 参照) 北壁は設けられることなく，各本殿は独立して いたのであろう。ところが延久 3 年になると，馬道間に 遷座するが故に仮板を敷き，北側には壁を設け，造合閐 の如く仮設して，三宇連棟の先鞭となった。

最後に石清水八幡宮の方々, 谷村家の方々に感謝の意 を表わすしだいである。

[注]

注1）石清水遷座緣起（石清水文書之一）

（前略）今奉 奏狀惑悦所令奉造也者, 貞観立年过辰造 


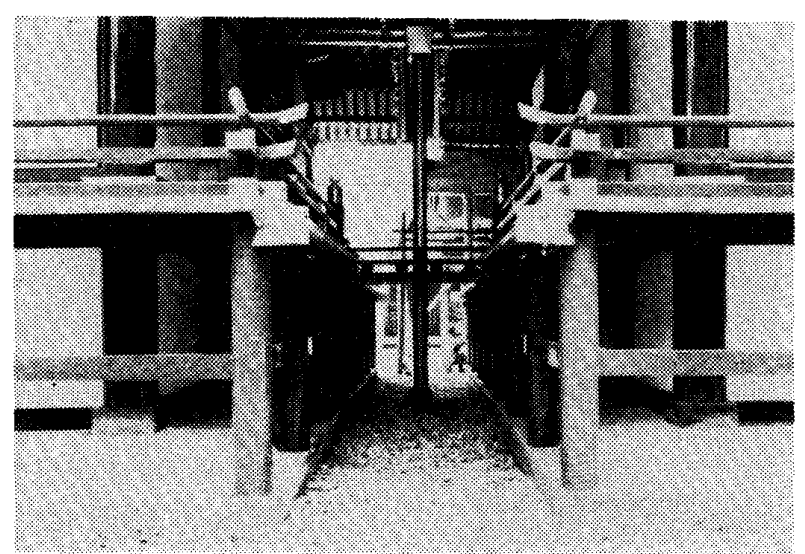

図一6 内殿と内殿との間（宇佐八幡宮）

立寶殿, 隨則安置御像, 霊駩彌陀, 感憵自洽, (以下略) 寛喜四年二月廿日 権別當法印 (花押) (・印筆者)

注2）石清水八幡宮御修理造営之記（石清水文書之四） 後一條院御宇

長元二年, 御殿北高闌秆前後犬防幣殿南樓階日隱等始造 之

長元之比, 別當法印元命申云, 奉移外殿, 修造内殿還御 本所之後, 可修外殿欺, 有計申旨, 然而有沙汰被遂行, 不詳云々

注3）古絵図は掛軸になっている絵図の一部揭載

裏書日

貞和二年十月四日感得之

有此図岩本坊

宝曆八年四月十五日 谷村正稳写

寛政五年五月廿四日 谷村久輔模写焉

石清水八幡宮と同じ八幡町に在住の谷村家に代々伝えら れた絵図で現在谷村家に所蔵してある。

注4）石清水八幡宮御修理造営之記（石清水文書之四）

陰陽寮

擇申可被修理石清水八幡宮御殿日時

今月廿九日戊子 時巳二點 若午

延久二年四月十四日助兼権暦博士賀茂朝臣道榮 頭兼暦博士出雲権介賀茂朝臣道言 主税頭兼陰陽博士楎権守賀茂朝臣道平

注5）石清水八幡宮御修理造営之記（石清水文書之四）

擇申可被造替第二 御殿朽損梁日時

木作日時

今月九日甲午 時巳未

上梁日時

十五日庚子 時辰已

四月九日甲子 時巳未

延久三年三月六日 主税頭賀茂朝臣道平

擇申可被修造 御殿雜事日時

作假板敷日時
四月五日庚申 時巳午

奉渡御躰於假板敷日時

$$
\text { 九日甲子 時寅 記一巻有 }
$$

奉還御躱日時

十五日庚午 時亥

\#二日丁丑 時戍

奉渡御躰於䈔板敷事

以件日時被奉渡之草

手史等参仕也, 但日内奉還御也

延久三年三月甘日主税頭賀茂朝臣道平

注6）八幡宮寺縁事抄（石清水八幡宮史）

一當社西門脇劍御前造立事

長宽年中御殿扞四面廊有修理, 其次又劍御座始造之,

検校㬺清持也

陰陽寮日時勘丈（石清水文書之一）

陰陽寮

擇申可被修理石清水宮雜事日時

始木作日時

今月廿七日乙卯 時辰二點 若申

修理日時

十月七日甲子 時巳二點 若末 長宽元年九月十五日 (以下略)

注7）東大寺文書（石清水八幡宮史）

端售書)

建久四年八月十五日 八幡宮一日御修理事

勅使佐中辨正四位下藤親經

道々工 給淨农

木工八十三人内宮工廿人檜皮工百人内宮工二十人

壁工六人 金物細工十九人

朱砂塗五人宮寺加冶六人宮寺

已上二百十九人（以下略）

注8）石清水八幡宮御修理造営之記（石清水文書之四）

順德院御宇一日御修理

承久元年八月十五日放生會一日御修理

（中略）

御修理事, 兼日經奏聞, 今日古一日中奉修造内殿, 建 久之御修理二八令半損之間, 諸庄吕物等今度令半減畢, 職事蔵人宮内権大輔家光, 弁, 左中弁藤原宣等也, 委細 在別記, (・印筆者)

注9）石清水八幡宮御修理造営之記（石清水文書之四）

$$
\text { 延久年中 }
$$

（實）

上卿左大臣極殿権左中方隆方朝臣奉之

件假殿踓造立, 依不可奉移御射之儀出來, 被破却畢, 去 月十六日被行御占果, 御占在之, 御占申奉移無崇之由, 但 雖不及假殿遷宮, 被修造本殿板敷之間, 本殿内口間許奉 移動之, 被行本殿修理果, 以之案之, 御占 違之儀歕，（・印筆者） 
U.D.C. $72.03: 389$

\title{
A STUDY ON THE PROPORTIONAL SYSTEM IN THE JAPANESE TRADITIONAL TYPE
}

On the Relational System of the Buddist Architectune in the Heian Period. No. 1 (Statestical Analysis of the Specimens. No. 4)

by TAMOTU. IWATATE, Assist Prof. of Kyushu Kiyoritu Univ. Member of A.I.J.

As I have descrived in the previous paper, the ancient Architectures have a lange error of dimension, therefor, if I have a order from this study, we can not assume this conclusion as a strict meaning.

The conclusion of this study shall be discrived a next dissertation.

U.D.C. 726.139 .52

\section{ON THE MAIN SHRINE OF IWASHIMUZU-HACHIMAN SHRINE}

\author{
by MISSUYOSHI TSUCHIDA, Lecturer of Kyushu Univ. Member \\ of A.I.J.
}

The main shrine of Iwashimuzu-Hachiman shrine was built in A.D. 860, and was repaired till 1371 without the removal of a temporary shrine. But the goddess on the west side was removed in the horse-way once for all in order to be repaired in 1071. Three shrines were separate in A.D. 860. The main shrine was repaired in 1071, and then the shrines were continued. The shrine was burnt in 1140 and the continued shrine was reconstructed. At present the form of the main shrine is continued since 1140. My paper on the architectural aspects of this shrine consisti of these four parts.
1. Introduction
2. The removal of a temparary shrine.
3. The reparation in 1071 .
4. Conclusion. 